ditions, occasionally results in renal wasting of other substances, such as potassium (Sanderson, 1967) and amino-acids (Cusworth et al., 1970), which may be reversible when the hypercalcaemia is corrected. The defective renal conservation of magnesium in our patients, which was often associated with slight urea retention, may be a similar and sometimes reversible effect of primary byperparathyroidism.

I ain grateful to Professor C. E. Dent for advice in the preparation of this paper, and to Dr. Lyal Watson for continued guidance and encouragement. I also thank Mr. V. K. Asta for preparing the diagrams.

\section{REFERENCES}

Agna, J. W., and Goldsmith, R. E. (1958). New England fournal of Medicine, 258, 222.

Barnes, B. A., Krane, S. M., and Cope, O. (1957). Fournal of Clinical Endocrinology and Metabolism, 17, 1407

Briscoe, A. M., and Ragan, C. (1967). Nature, 214, 1126.

Bulger, H. A., and Gausmann, F. (1933). Fournal of Clinical Investigation, 12,1135 .

Care, A. D., Sherwood, L. M., Potts, J. T., jun., and Aurbach, G. D. (1966). Nature, 209, 55.
Clarkson, E. M. McDonald, S. J, de Wardener, H. E, and Warren, R (1965). Clinical Science, 28, 107

Cusworth, D. C., Dent, C. E., and Scriver, C. R. (1970). In preparation Davies, D. R., Dent, C. E., and Watson, L. (1968). Britich Medical fournal, 3, 395

Dent, C. E. (1962). British Medical foumal, 2, 1419.

Dent, C. E., Harper, C. M., and Philpot, G. R. (1961). Quarteriy fournal of Medicine, 30, 1

Dent, C. E., and Watson, L. (1968). Lancet, 2, 662.

Dick, M. (1967). Fournal of Clinical Pathology, 20, 216

Dunn M J. and Walser, M. (1966). Metabolism, 15,884.

Fitzgerald, M. G., and Fourman, P. (1956). Clinical Science, 15, 635

Hanna, S., North, K. A. K., MacIntyre, I., and Fraser, R. (1961). British Medical fournal, 2, 1253 .

Harmon, M. (1956). American Fournal of Diseases of Children, 91, 313.

Heaton, F. W. (1966). Quoted by L. N. Pyrah, A. Hodgkinson, and C. K. Anderson, British fournal of Surgery, 1966, 53, 245.

Heaton, F. W., and Fourman, P. (1965). Lancet, 2, 50.

Jones, K. H., and Fourman, P. (1966). Clinical Science, 30, 139.

MacDonald, M. A., and Watson, L. (1966). Clinica Chimica Acta, 14, 233.

Macintyre, I., Boss, S., and Troughton, V. A. (1963). Nature, 198, 1058

Reifenstein, E. C., Albright, F., and Wells, S. L. (1945). Fournal of Clinical Endocrinology, $5,367$.

Sanderson, P. H. (1967). British Medical fournal, 1, 679.

Shelp, W. D., Steele, T. H., Deluca, H. F., and Reiselbach, R. E. (1966). Clinical Research, 14, 448.

Steele, T. H., Wen, S.-F., Evenson, M. A., and Reiselbach, R. E. (1968). Fournal of Laboratory and Clinical Medicine, 71, 455.

Sutton, R. A. L., and Watson, L. (1969). Lancet, 1, 1000.

Zimmet, P., Breidahl, H. D., and Nayler, W. G. (1968). British Medical fournal, 1, 622 .

\title{
Practolol in Treatment of Supraventricular Cardiac Dysrhythmias
}

\author{
GRAHAM GENT,* M.A., M.B., B.CHIR. ; TIMOTHY C. DAVIS, † м.в. \\ ALASTAIR MCDONALD, $\ddagger$ B.SC., M.R.C.P., M.R.C.P.ED.
}

$S^{\text {u }}$ mmary: Practolol (I.C.I. 50172) was used to treat supraventricular dysrhythmias in 32 patients with a rapid ventricular rate and with heart disease of varied aetiology. In 26 patients the average reduction in ventricular rate was 75 per minute, while immediate reversion to sinus rhythm occurred in three patients. The slowing effect was mainly due to a direct action on the atrioventricular node. The effectiveness of practolol was unrelated to the type of dysrhythmia or its aetiology. No serious adverse clinical effects were noted.

\section{Introduction}

Practolol (I.C.I. 50172) is a cardioselective beta-adrenergic receptor blocking drug with weak sympathomimetic properties (Barrett et al., 1967; Brick et al., 1968). It lacks local anaesthetic and quinidine-like actions and therefore has no direct depressant effect on the myocardium. The use of the drug in the management of supraventricular dysrhythmias has been encouraging (Gibson et al., 1968; Jewitt et al., 1969). We report here our clinical experience with intravenous practolol given to patients with supraventricular dysrhythmias associated with a rapid ventricular rate.

\footnotetext{
* Research Fellow

† Registrar.

Cardiac Department, the London Hospital, London E.1
}

\section{Patients Studied}

Practolol was given to 32 patients (see Table) who had various cardiac lesions. Fifteen had rheumatic heart disease and four had undergone recent heart valve replacement-the mitral valve in three and both aortic and mitral valves in one. Three patients with calcific aortic stenosis had recently had aortic valve replacement. Ischaemic heart disease was the underlying cardiac lesion in seven patients, recent cardiac infarction having occurred in two. Six patients had prolonged attacks of paroxysmal tachycardia, associated with Wolff-Parkinson-White syndrome in four, and one patient had a fossa ovalis atrial septal defect. Clinical and radiological evidence of heart failure was present in 22 patients and in eight the failure was severe.

Practolol was injected intravenously with electrocardiographic control in a dose of $2 \mathrm{mg}$./minute until a therapeutic effect was noticed or a total of $20 \mathrm{mg}$. had been given.

\section{Results}

The response of the ventricular rate to practolol and the dosages required are shown in the Table. The effect of the drug was apparent within a few minutes of administration. The maximum dosage was $12 \mathrm{mg}$. in the 26 who responded, but usually the effective dose was between 5 and $10 \mathrm{mg}$. In six cases there was no response to the drug, the ventricular rate being unchanged after $20 \mathrm{mg}$. of practolol.

Atrial Fibrillation.-Before administration of practolol the 
Details of Patients, Dysrhythmias, and Response to Practolol

\begin{tabular}{|c|c|c|c|c|c|c|c|c|}
\hline \multirow{2}{*}{$\begin{array}{l}\text { Case } \\
\text { No. }\end{array}$} & \multirow{2}{*}{\multicolumn{2}{|c|}{$\begin{array}{l}\text { Age } \\
\text { and } \\
\text { Sex }\end{array}$}} & \multirow[t]{2}{*}{ Aetiology } & \multirow{2}{*}{$\begin{array}{l}\text { Cardiac } \\
\text { Failure }\end{array}$} & \multicolumn{2}{|c|}{ Heart Rate/min. } & \multirow{2}{*}{$\begin{array}{c}\text { Dose of } \\
\text { Practolol } \\
\text { (mg.) }\end{array}$} & \multirow{2}{*}{$\begin{array}{l}\text { Rhythm } \\
\text { Change }\end{array}$} \\
\hline & & & & & Before & After & & \\
\hline \multicolumn{9}{|c|}{ Atrial fibrillation } \\
\hline 1 & 49 & $\mathrm{~F}$ & $\begin{array}{l}\text { Aortic valve } \\
\text { replacement }\end{array}$ & - & 150 & 100 & 6 & - \\
\hline 2 & 41 & & $\begin{array}{l}\text { Mitral valve } \\
\text { replacement }\end{array}$ & $+t+$ & 180 & 100 & 6 & $\begin{array}{l}\text { Sinus } \\
\text { rhythm }\end{array}$ \\
\hline 3 & 48 & $M$ & Mitral valve & ++ & 150 & 105 & 10 & - \\
\hline 4 & 34 & $\mathbf{M}$ & R.H.D. & +++ & 180 & 100 & 8 & - \\
\hline 5 & 54 & $\mathbf{F}$ & R.H.D. & $+t+$ & 160 & 95 & 10 & - \\
\hline 6 & 35 & $\mathrm{~F}$ & R.H.D. & + & 200 & 100 & 8 & - \\
\hline 7 & 52 & $F$ & R.H.D. & ++ & 180 & 95 & 12 & - \\
\hline 8 & 37 & $\mathrm{~F}$ & R.H.D. & - & 160 & 160 & 20 & - \\
\hline 9 & 61 & $\mathbf{M}$ & I.H.D., C.I. & - & 180 & 100 & 10 & - \\
\hline 10 & 64 & $\mathbf{M}$ & I.H.D., C.I. & +++ & 160 & 110 & 10 & - \\
\hline 11 & 51 & $\mathbf{M}$ & I.H.D. & - & 150 & 90 & 8 & - \\
\hline \multicolumn{9}{|c|}{ Atrial Flutter 130} \\
\hline 12 & 55 & $M$ & R.H.D. & - & 130 & 90 & 10 & A.F. \\
\hline 13 & 53 & $M$ & R.H.D. & - & 170 & 90 & 10 & $\begin{array}{l}3: 1 \\
\text { A/V block }\end{array}$ \\
\hline 14 & 67 & M & R.H.D. & - & 140 & 100 & 6 & $\begin{array}{l}3: 1 \text { \& } 2: 1 \\
\mathrm{~A} / \mathrm{V} \text { block }\end{array}$ \\
\hline 15 & 55 & $\mathbf{F}$ & R.H.D. & $+t+$ & 160 & 80 & 10 & A.F. \\
\hline 16 & 75 & M & I.H.D. & + & 140 & 90 & 8 & $\begin{array}{l}3: 1 \\
\mathrm{~A} / \mathrm{V} \text { block }\end{array}$ \\
\hline 17 & 62 & M & A.S.D. & +++ & 160 & 80 & 10 & $\begin{array}{l}4: 1 \\
\mathrm{~A} / \mathrm{V} \text { block }\end{array}$ \\
\hline 18 & 48 & $M$ & P.T. & - & 125 & 80 & 8 & $\begin{array}{l}4: 1 \\
\text { A/V block }\end{array}$ \\
\hline 19 & 51 & M & $\begin{array}{l}\text { Aortic valve } \\
\text { replacement }\end{array}$ & + & 160 & 80 & 12 & $\begin{array}{l}4: 1 \\
\mathrm{~A} / \mathrm{V} \text { block }\end{array}$ \\
\hline \multicolumn{9}{|c|}{ Supraventricular tachycardia } \\
\hline 20 & 56 & $\mathrm{~F}$ & $\begin{array}{l}\text { Aortic and mitral } \\
\text { valve } \\
\text { replacement }\end{array}$ & ++ & 180 & 65 & 12 & $\begin{array}{l}\text { Sinus } \\
\text { rhythm }\end{array}$ \\
\hline 21 & 50 & M & $\begin{array}{l}\text { Aortic valve } \\
\text { replacement }\end{array}$ & ++ & 160 & 160 & 20 & - \\
\hline 22 & 56 & $\mathrm{~F}$ & $\begin{array}{l}\text { Mitral valve } \\
\text { replacement. } \\
\text { Digitalis } \\
\text { overdosage }\end{array}$ & ++ & 200 & 90 & 8 & - \\
\hline 23 & 61 & $\mathrm{~F}$ & R.H.D. & + & 180 & 100 & 10 & $\begin{array}{l}2: 1 \\
\mathrm{~A} / \mathrm{V} \text { block }\end{array}$ \\
\hline 24 & 56 & $\mathbf{F}$ & R.H.D. & - & 160 & 80 & 8 & $\begin{array}{l}2: 1 \\
\mathrm{~A} / \mathrm{V} \text { block }\end{array}$ \\
\hline 25 & 64 & $\mathbf{F}$ & $\begin{array}{l}\text { I.H.D. } \\
\text { Ventricular } \\
\text { aneurysm }\end{array}$ & $+t+$ & 200 & 140 & 10 & $\begin{array}{l}\text { Varying } \\
\mathrm{A} / \mathrm{V} \text { block }\end{array}$ \\
\hline 26 & 55 & F & $\begin{array}{l}\text { I.H.D. } \\
\text { Digitalis } \\
\text { overdosage }\end{array}$ & $+t+$ & 180 & 90 & 12 & A.F. \\
\hline 27 & 64 & F & $\begin{array}{l}\text { I.H.D. } \\
\text { Digitalis } \\
\text { overdosage }\end{array}$ & + & 160 & 80 & 8 & $\begin{array}{l}\text { Sinus } \\
\text { rhythm }\end{array}$ \\
\hline 28 & & $\mathrm{~F}$ & P.T. & + & 180 & 100 & 12 & $\begin{array}{l}2: 1 \\
\mathrm{~A} / \mathrm{V} \text { block }\end{array}$ \\
\hline 29 & 60 & $\mathrm{~F}$ & W.P.W. & ++ & 180 & 180 & 20 & - \\
\hline 30 & 45 & F & W.P.W. & + & 180 & 180 & 20 & - \\
\hline 31 & 40 & $\mathrm{~F}$ & W.P.w. & - & 200 & 200 & 20 & - \\
\hline 32 & 60 & $\mathbf{M}$ & W.P.w. & + & 250 & 250 & 20 & - \\
\hline
\end{tabular}

R.H.D. = Rheumatic heart disease. I.H.D. $=$ Ischaemic heart disease. C.I $=$ Cardia infarction. A.S.D. = Atríal septal defect. W.P.W. = Wolf-Parkinson-White syndrome. P.T. = Paroxysmal tachycardia. A.F. = Atrial fibrillation

ventricular rate (averaged over 10 consecutive beats) was 150/ minute or greater in all 11 patients. No effect on the rate was produced in one patient, and in the other 10 a mean reduction in ventricular rate of 70 beats per minute was induced, with reversion to sinus rhythm in one case. Six patients were already receiving digitalis. In two patients practolol was continued orally in a dose of $50 \mathrm{mg}$. twice daily in addition to digitalis to maintain control of the ventricular rate. While practolol was effective acutely in one patient increasing oral administration to
$300 \mathrm{mg}$. a day failed to maintain control. In this latter patient a number of digitalis preparations used to toxic doses had failed to control the rate, as had propranolol; treatment with reserpine now appears to be controlling the ventricular rate.

Atrial Flutter.-Eight patients had atrial flutter and were receiving digitalis. In six with ventricular rates of 140 or more per minute $2 / 1$ atrio ventricular block was present; in the remaining two, with slightly slower rates, there was varying $2 / 1$ and $3 / 1$ atrioventricular block. In all eight patients an increase in the atrioventricular block resulted in a ventricular rate of $100 /$ minute or less. In two patients a small decrease in the flutter rate was noted. In two cases the rhythm changed to atrial fibrillation with a controlled ventricular response. One patient reverted to sinus rhythm with subsequent oral administration of $100 \mathrm{mg}$. of practolol daily. Cessation of the drug led to atrial flutter returning, but on recommencing practolol sinus rhythm was regained. The higher atrioventricular ratio was maintained by oral therapy in two patients; reversion to sinus rhythm some hours later occurred in two patients; atrial fibrillation returned in one patient with further digitalis therapy.

Supraventricular Tachycardia.-There were 13 patients with other supraventricular tachycardias. The ventricular rate varied from 160 to $250 /$ minute and in the eight patients who responded an average reduction of $90 /$ minute was achieved. Seven were receiving digitalis, and in three it was considered that digitalis overdosage was the cause of the dysrhythmia. After treatment with practolol two patients reverted to sinus rhythm, and one patient returned to atrial fibrillation. In four patients the ventricular rate was controlled by inducing $2 / 1$ atrioventricular block (see Figure). In one patient who appeared
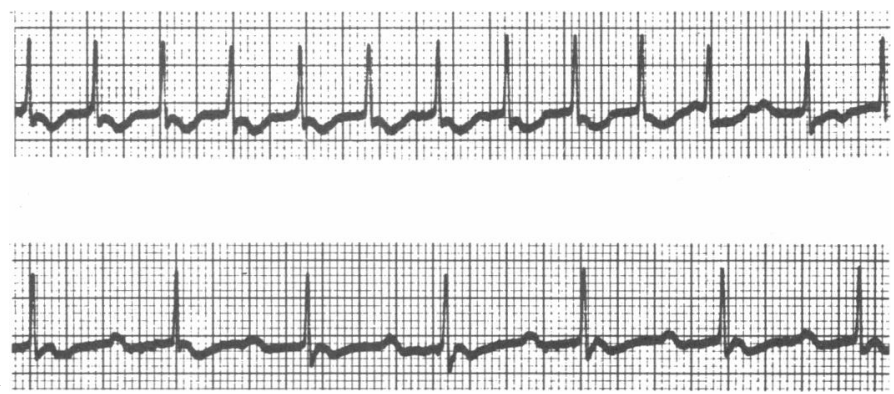

Electrocardiogram, lead II. Top, showing supraventricular tachycardia, ventricular rate 160 per minute. Bottom, after $8 \mathrm{mg}$. practolol, 2:1 atrioventricular block, ventricular rate 80 per minute.

to have a nodal tachycardia the ventricular rate was slowed but the mechanism of slowing was uncertain. Reversion to sinus rhythm some hours later occurred in two patients, and atrial fibrillation developed in one other. The $2 / 1$ atrioventricular block was maintained with digitalis in one patient and with oral practolol in another. No effect was seen in five patients. The four patients with Wolff-Parkinson-White syndrome showed no response to practolol.

\section{Clinical Response to Practolol}

In 10 patients who were tolerating the rapid ventricular rate well no clinical deterioration occurred, and in 21 patients in heart failure there were no side-effects. The remaining patient in heart failure who had Wolff-Parkinson-White syndrome and a supraventricular tachycardia developed hypotension, systolic pressure less than $100 \mathrm{~mm}$. $\mathrm{Hg}$, after $20 \mathrm{mg}$. of practolol had no slowing effect. Sinus rhythm was restored after rapid intravenous digitalization with ouabain with correction of the hypotension. Six out of eight patients in the early postoperative period had shown deterioration with the development of a fast ventricular rate, and in the five who showed a 
good response to practolol this deterioration was reversed. Controlling the ventricular rate in one patient with extensive cardiac infarction and heart failure did not result in improvement, and the patient died some days later with uncontrolled heart failure. The dysrhythmias were superimposed on chronic heart failure in 11 patients and the effect of controlling the ventricular rate was less impressive, but in all patients the failure was subsequently controlled with conventional therapy, except in the patient with an atrial septal defect and gross heart failure who required peritoneal dialysis to control the failure.

\section{Discussion}

In the management of supraventricular dysrhythmias with a rapid ventricular rate digitalization remains the principal mode of therapy. Even with rapidly acting digitalis preparations, however, such as ouabain used intravenously, full digitalization may not be achieved safely unless the digitalizing dose is given over one to two hours. If direct-current shock is contemplated there are increased hazards in the fully digitalized patient. As the efficacy of practolol in this situation can be judged within minutes and alternative therapeutic possibilities are not influenced, practolol is a useful adjunct to antidysrhythmic drugs, and successful control of the ventricular rate is likely in most cases. Only six of the 32 patients failed to respond. Similar results have been reported principally in postoperative dysrhythmias and in patients with acute cardiac infarction. The use of practolol in the treatment of supraventricular tachycardias associated with Wolff-Parkinson-White syndrome has not previously been reported, and all four patients in this series failed to respond. This is in contrast to the effect of propranolol (Stock, 1966), suggesting that the antidysrhythmic effect of propranolol in this situation is related to its quinidinelike effect and not to its beta-adrenergic receptor blocking action.

As with other beta-adrenergic blocking drugs the possibility of provoking or aggravating heart failure must be considered (Stock and Dale, 1963; Stephen, 1966; Conway et al., 1968). Haemodynamic studies (Shinebourne et al., 1968; Sowton $e t$ al., 1968) have shown that $5 \mathrm{mg}$. of practolol, while slowing the heart, does not reduce the cardiac output, but in higher dosage a modest reduction in cardiac output results. Only one patient in this series showed clinical evidence of haemodynamic deterioration after $20 \mathrm{mg}$. of practolol had failed to produce a beneficial slowing effect. The risks are probably less with practolol than with other drugs such as propranolol, which in addition to its beta-adrenergic blocking action has a direct myocardial depressant effect.

The slowing effect of practolol was mediated through a direct action on the atrioventricular node in 22 of the 23 patients who responded without a return to sinus rhythm. In the remaining case the precise mechanism of slowing was not clearly established.

Our experience with long-term administration of practolol to maintain control of the ventricular rate is limited to six patients, in five of whom it was effective for periods extending up to nine months. We do not, however, consider the drug to be an alternative to digitalis, which has additional benefit other than control of rate. In some " resistant" patients practolol controls the heart rate when digitalis alone has been inadequate.

We thank Dr. R. A. Wiseman for supplies of practolol, and Dr. W. Brigden and Dr. L. McDonald for permission to study patients under their care and for advice during the preparation of this paper.

Request for reprints to Dr. G. M. Gent.

\section{REFERENCES}

Barrett, M., et al. (1967). Cardioselective Beta Blockade: Pharmacological studies with I.C.I. 50172, Macclesfield.

Brick, I., Hutchison, K. J., McDevitt, D. G., Roddie, I. C., and Shanks, R. G. (1968). British fournal of Pharmacology, 34, 127.

Conway, N., Seymour, J., and Gelson, A. (1968). British Medical fournal, 2, 213.

Gibson, D. G., Balcon, R., and Sowton, E. (1968). British Medical fournal, 3, 161.

Jewitt, D. E., Mercer, C. J., and Shillingford, J. P. (1969). Lancet, 2,

Shinebourne, E., Fleming, J., and Hamer, J. (1968). Cardiovascular $R e$ search, 2, 379.

Sowton, E., Balcon, R., Cross, D., and Frick, H. (1968). British Medical fournal, 1, 215

Stephen, S. A. (1966). American fournal of Cardiology, 18, 463.

Stock, J. P. P. (1966). American fournal of Cardiology, 18, 444.

Stock, J. P. P., and Dale, N. (1963). British Medical fournal, 2, 1230.

\title{
Rate of Disappearance of Endogenous Insulin from the Circulation after Removal of Insulinomas
}

\author{
B. J. BOUCHER,* M.D., M.R.C.P.; R. J. FRANKEL, † M.B., B.CH., M.R.C.P.; P. WALTERS, $\ddagger$ B.SC. \\ M. ABEL, $\ddagger$ B.SC.
}

\begin{abstract}
Cummary: In two patients with insulinomas a rapid $\checkmark$ rate of disappearance of insulin from the circulation was found after the tumours had been removed. In a third case the rate of disappearance was slower but the insulin was not immunologically identical to normal human insulin standards, as it was in the other two cases.
\end{abstract}

\footnotetext{
* Physician.

Lecturer, Medical

Department of Metabolism and Endocrinology, London Hospital, London E.1.
}

It has been suggested in the past that the half-time of disappearance of insulin from the circulation might be about 35 minutes using radioiodine-labelled insulin (Berson et al., 1956). Samols and Marks (1966) and Williams et al. (1968) measured the rate of fall of endogenous immunoreactive insulin in man at the cessation of prolonged glucose and glucagon infusions and found half-times of insulin disappearance of 7 to 15 minutes. As has been pointed out (Stimmler, 1966) there is no certainty that insulin secretion stops instantly in such studies, and if it did continue at all 